\author{
Adam Bartczak*
}

\title{
KONWALIDACJA MAŁŻEŃSTWA KANONICZNEGO
}

\begin{abstract}
Streszczenie. Konwalidacja małżeństwa w prawie kanonicznym jest instytucją, procesem, w którym nieważnie zawarte małżeństwo zostaje uważnione w świetle prawa. W niniejszym artykule została podjęta problematyka konwalidacji, zwłaszcza w perspektywie samego nazewnictwa używanego przez autorów polskojęzycznych. Kanwą rozważań stało się rozróżnienie dwóch form konwalidacji, tj. konwalidacji zwykłej i uzdrowienia w zawiązku. W nomenklaturze przyjętej na gruncie polskiej kanonistyki używa się w zasadzie jednego określenia - uważnienie na określenie tych dwóch form, oczywiście przy jednoczesnym ich rozróżnieniu. Konwalidacja ma zasadnicze znaczenie w prawie kanonicznym, ponieważ nadaje skuteczność prawną małżeństwu, które przecież faktycznie istnieje.
\end{abstract}

Słowa kluczowe: małżeństwo, skuteczność, konwalidacja, zgoda małżeńska, wada.

Małżeństwo kanoniczne od zawsze cieszyło się specjalną ochroną ze strony Kościoła jako naturalna umowa małżeńska podniesiona, zgodnie z zamysłem Bożym, przez Chrystusa do godności sakramentu. Sakrament małżeństwa jest znakiem związku Chrystusa i Kościoła (KKK, 1661). W Konstytucji duszpasterskiej Gaudium et spes czytamy, że przymierze małżeńskie tworzy głęboką wspólnotę życia i miłości małżeńskiej. W ten sposób powstaje instytucja trwała również wobec społeczeństwa (Gaudium et spes, 48). Tak powstała wspólnota cieszy się jednością i nierozerwalnością - przymiotami charakterystycznymi dla małżeństwa katolickiego. Nadto małżeństwo staje się podstawą rodziny, z której na świat przyjdzie potomstwo. Chroniąc istotne przymioty i cele małżeństwa, Kościół zawsze głosił naukę o małżeństwie oraz bronił jego ważności. Natomiast w sytuacji, kiedy mamy do czynienia z małżeństwem zawartym prawnie nieważnie, Kościół - jeśli jest to możliwe - dąży do naprawy tego stanu poprzez instytucję nazywaną w kanonistyce konwalidacją.

\section{POJECIE KONWALIDACJI}

Prawodawca kościelny w Kodeksie prawa kanonicznego z 1983 r. na określenie tej instytucji prawnej używa terminu convalidatio. Taką nazwę nosi zresztą cały rozdział dziesiąty dotyczący małżeństwa w Kodeksie prawa kanonicznego,

* Uniwersytet Łódzki, Wydział Prawa i Administracji, Katedra Teorii i Filozofii Prawa, abartczak@wpia.uni.lodz.pl. 
w skład którego wchodzą dwa artykuły odnoszące się do dwóch rodzajów konwalidacji, a mianowicie convalidatio simplici oraz sanatio in radice. Aby lepiej zrozumieć pojęcie konwalidacji, trzeba dokonać dogłębnej analizy słowotwórczej tego określenia. Wskazuje ona na jego złożoną budowę. Termin convalidatio składa się z przedrostka con- oraz tematu -validatio. Tenże pochodzi od czasownika valeo oznaczającego bycie zdrowym, silnym (Jougan 2013, 715), bycie dosyć silnym, aby coś zrobić, a także mieć autorytet prawny, moc prawną, być ważnym, wiążącym, obowiązującym, obowiązywać (Korpanty 2003, 924). Od tegoż czasownika pochodzą również: rzeczownik validitas - ważność, znaczenie, jak i przymiotnik validus - zdrów, mocny, silny, skuteczny (Jougan 2013, 716), mający moc prawną, ważny, obowiązujący (Korpanty 2003, 925). Przedrostek con-, nieistniejący jako samodzielny wyraz, ale użyty przed czasownikiem, równy jest przyimkowi cum, który znaczy: z, razem z (Kopaliński 1989, 269). W słownikach łacińsko-polskich można odnaleźć czasownik convalescere. Oznacza on: stawać się silnym, nabierać sił; okrzepnąć; dobrze się rozwijać; ale także: zyskiwać nowe znaczenie, wzrastać w znaczenie, siłę. Wreszcie należy przytoczyć znaczenie stricte prawne, a mianowicie: nabierać mocy prawnej, stawać się obowiązującym (Korpanty 2001, 440-441). W słowniku kościelnym A. Jougana można odnaleźć więcej określeń i zwrotów dotyczących omawianego pojęcia. Autor thumaczy termin convalesco również jako: uzyskiwać ważność, stawać się mocniejszym, mocnym, wyzdrowieć (Jougan 2013, 155). A. Jougan wprowadził też pojęcie convalidatio, które przekłada jako (uzupełniające, dodatkowe) uznanie prawomocności i przywrócenie wszelkich skutków prawnych, uznanie za ważne małżeństwa nieważnego (tamże).

Jak widać, łaciński termin convalidatio nie jest tłumaczony na język polski przy pomocy jednego znaczenia. Tłumacze tekstu kodeksowego podają nam na jego określenie najczęściej zwrot „uważnienie” (kan. 1156-1160 KPK). Wydaje się, że jest to nazwa nieprzypadkowa, albowiem w terminologii kanonistycznej termin ten pojawił się już pod rządami Kodeksu prawa kanonicznego z 1917 r. Ponadto, w kanonistyce termin ten jest używany powszechnie. Posługują się nim kanoniści w okresie obowiązywania kodeksu pio-benedyktyńskiego z 1917 r., a także kodeksu Jana Pawła II z 1983 r., m.in.: S. Biskupski (1956, 437-450), M. Gajda (2002, 258-263), W. Góralski (2006, 349-359), T. Pawluk (1984, 228-230), E. Sztafrowski (1979, 311-315; 1986, 172-177), M. Żurowski (1976, 413-424). Jednym słowem, termin ten przyjął się w polskiej nomenklaturze kanonistycznej. Odnajdziemy jednak również inne określenia. W. Szafrański używa pojęcia „uprawomocnienie małżeństwa” (Szafrański 1971, 277-279). Można się też spotkać z terminem „uzdrowienie małżeństwa” (Kasprzak 2000, 684-686). Z. Janczewski używa terminu „uważnienie” jako synonimu słowa „konwalidacja” (Janczewski 2008, 1007). Warto zaznaczyć, iż czynią tak i inni kanoniści. Dla rozróżnienia warto przytoczyć polskiego kanonistę, F. Bączkowicza, który posługuje się jedynie określeniem „konwalidacja małżeństwa” (Bączkowicz 1933, 
176-182). Natomiast wśród kanonistów zagranicznych można zauważyć posługiwanie się wyłącznie terminem convalidatio (Brennan 1937; Cappello 1923, 887-897; Chelodi 1921, 179-182; Tallarico 1938; Wernz, Vidal 1925, 787-794).

Patrząc na problem pojęcia konwalidacji w języku polskim, można zauważyć jeszcze inne dwa aspekty. Po pierwsze, w tłumaczeniu kodeksowym odnajdujemy użycie słowa „uważnienie” zarówno w odniesieniu do konwalidacji in genere, jak i w odniesieniu do dwóch rodzajów konwalidacji, tj. simplice oraz sanatio in radice, które kodeks odróżnia. A zatem w przekładzie na język polski nie odnajdujemy żadnej różnicy pomiędzy tymi rodzajami. Po drugie, przeprowadzone badania wykazały, że w słownikach języka polskiego nie można odnaleźć terminu/pojęcia ,uważnienie”. A więc jako takie nie jest ono skatalogowane, choć rozumiem, że zostało wprowadzone do języka prawniczego w polskiej kanonistyce. Jednak czy oddaje ono w pełni pojęcie konwalidacji, zamierzone przez prawodawcę, i to w obydwu jej rodzajach? „Uważnienie” generalnie w polskiej terminologii kanonistycznej oznacza: sprawienie, że małżeństwo, które było uprzednio nieważnie zawarte, staje się ważne wobec prawa po spełnieniu warunków przewidzianych prawem. Natomiast ze słowem „konwalidacja” spotykamy się w różnych encyklopediach czy słownikach. W Encyklopedii popularnej $P W N$ pod hasłem ,konwalidacja” czytamy, iż jest to uznanie za ważną, wskutek dodatkowego zdarzenia, czynności prawnej pierwotnie wadliwej (Encyklopedia... 1982, 363). Słownik wyrazów obcych podaje, że „,konwalidacja” to uzyskanie przez czynność prawną (pierwotnie wadliwą) pełnej mocy prawnej na skutek nowych okoliczności (Szkiłądź 1980, 388). Również w opracowaniach dotyczących polskiego prawa rodzinnego znajdziemy instytucję „konwalidacji” małżeństwa (Ignatowicz 2002, 209-2011), a nie, terminologicznie, ,uważnienia” małżeństwa. Także polskie prawo cywilne zna instytucję konwalidacji czynności prawnej. Aby jednak w pełni zrozumieć kwestię terminologiczną, należy przyjrzeć się istocie konwalidacji.

\section{ISTOTA KONWALIDACJI MAŁŻEŃSTWA}

Konwalidacja małżeństwa to akt prawny, mocą którego nieważnie zawarty związek małżeński staje się małżeństwem kanonicznie ważnym (Bączkowicz 1933, 176; Góralski 1986, 340; Wernz, Vidal 1925, 788)². Źródłem instytucji konwalidacji jest zatem nieważnie zawarte małżeństwo. Zgodnie z kan. $124 \S 1 \mathrm{KPK}$ do ważności aktu prawnego wymaga się, by był on dokonany przez zdolną do tego osobę oraz by były w nim zawarte wszystkie jego istotne elementy konstytutywne i zostały wypełnione formalności oraz warunki wymagane przez prawo

\footnotetext{
${ }^{1}$ „Convalidatio matrimonii est actus, quo matrimonium antea sub legitima specie et forma, sed nulliter celebratum ita resauratur, ut suum consequatur valorem".
} 
do ważności aktu (Dzierżon 2002, 60)². Do ważności zawarcia małżeństwa prawo wymaga braku jakiejkolwiek przeszkody zrywającej, zdolności konsensualnej oraz braku wad oświadczenia woli, a także dokonania tej czynności w formie kanonicznej. A zatem, aby mówić o konwalidacji, musimy mieć do czynienia z uprzednio nieważnie zawartym małżeństwem (kan. 1156 § 1 KPK: „Ad convalidandum matrimonium irritum").

Jak już zostało powiedziane, konwalidacja przybiera dwie formy: konwalidacja zwykła (convalidatio simplex) oraz konwalidacja nadzwyczajna, szczegółowo określana jako uzdrowienie w zawiązku (sanatio in radice) (Bączkowicz 1933, 176; Góralski 2006, 349; Gerosa 2002, 204; Sztafrowski 1986, 172-181). Niektórzy kanoniści w aspekcie konwalidacji małżeństwa, jak chociażby J. Hervada $\left(1987,826^{3}\right)$ czy A. Rava $(2001,267)$, zauważają obok tych dwóch modeli także trzeci, jakim jest zawarcie zupełnie nowego małżeństwa, które nie uchodzi jednak za prawdziwie właściwą konwalidację. J. Rybczyk stwierdza, iż już sam Kodeks z 1917 r., a za nim Kodeks prawa kanonicznego, mówiąc o uważnieniu małżeństwa, wyraźnie odgraniczał nazwę sanatio od nazwy convalidatio. Ta ostatnia jest użyta w kodeksie na oznaczenie zwykłego uważnienia, podczas gdy pierwsza oznacza szczególny sposób uważnienia. Nie jest to tylko przypadkowe rozróżnienie słowa, lecz wyraźne i celowe podkreślenie już w samej nazwie dwóch zupełnie różnych czynności prawnych (Rybczyk 1958, 20).

Podstawą dla tak przyjętego podziału jest bez wątpienia zgoda małżeńska. Zgodnie z kan. 1057 § 2 KPK małżeństwo powstaje przez zgodę stron, mężczyzny i kobiety, która nie może być uzupełniona żadną ludzką władzą. De facto nie może być ona przez nikogo oraz przez żaden inny akt prawny zastąpiona. Jest to fundamentalna zasada kanonicznego prawa małżeńskiego. Jak zauważa W. Góralski, zgoda stron jest na tyle zdolna stworzyć istnienie konkretnego małżeństwa kanonicznego, na ile, przynajmniej implicite, akceptuje istotę małżeństwa, określoną w całości przez prawo fundamentalne samej instytucji małżeństwa jako

${ }^{2}$,Zdolność jurydyczną aktu w danym systemie warunkuje m.in. korelacja pomiędzy zdolnością osoby a strukturą aktu prawnego. Zdolności tej jednak nie należy odnosić wyłącznie do elementów naturalnych jurydycznej konstrukcji aktu, lecz należy również wiązać ją ze wszystkimi komponentami aktu, wymaganymi przez prawodawcę do jego ważności. [...] zjawisko niezdolności do podjęcia aktu jest zagadnieniem niezwykle złożonym. Nie można bowiem mówić o jednej figurze niezdolności do powzięcia aktu, wręcz przeciwnie, należy mówić o wielu figurach w tej materii. Jest prawdą, iż każda z owych form powoduje nieważność aktu. Nieważność ta jednak nie w każdym przypadku jest jednakowo radykalna. W niektórych bowiem sytuacjach kompetentny autorytet, dla słusznej przyczyny, może dyspensować od wymagań ustanowionych prawem pozytywnym. Co więcej, w niektórych przypadkach nieważnie podjęty akt może również zostać uważniony”.

3 "Due sono precisamente la modalitàdi trasformare un matrimonio nullo in valido: la convalidazione semplice e la sanazione in radice. A queste due modalità se ne aggiunge un'altra che a rigor di termini non è una convalidazione: la nuova celebrazione del matrimonio. I cc. seguenti regolano le tre modalità indicate: convalidazione semplice, sanazione in radice e nuova celebrazione. [...] Quando si esige la forma per rinnovare il consenso, non c'è convalidazione, bensi nuova celebrazione". 
takiej (Góralski 2006, 46-47; Góralski, Dzierżon 2001, 35-364). Zgoda małżeńska jest aktem prawnym, którego podstawą jest actus humanus wyrażony w sferze zewnętrznej (Dzierżon 2000, 11). Ze strony wewnętrznej zgoda małżeńska jest aktem woli, angażującym jednocześnie wolę i intelekt. Akt wewnętrzny, jak zauważa G. Leszczyński, nie jest wystarczający do tego, aby stał się on aktem prawnym. Do zaistnienia actus iuridicus nie wystarcza bowiem wola wewnętrzna, lecz wymaga ona zewnętrznej formy, określonej przez prawodawcę (Leszczyński 2004, 42), a także zdolności prawnej nupturientów. Bez nich wola wewnętrzna nie jest przyczyną sprawczą małżeństwa (Viladrich 2002, 258)5. Należy jednocześnie zauważyć, iż zgoda małżeńska stanowi również zewnętrzną przyczynę formalną umowy (Góralski 2007, 314). Skoro zatem nie ma zgody, to także nie może być mowy o małżeństwie, albowiem zgodnie z kan. 1057 § 1 KPK „matrimonium facit partium consensus".

Kiedy jednak osoby na zewnątrz tworzą wspólnotę uważaną powszechnie za małżeństwo z racji jego zewnętrznego zawarcia, a faktycznie miała miejsce któraś z przesłanek nieważności małżeństwa, należy dopełnić formalności, aby związek cieszył się skutecznością prawną. Dlatego właśnie zgoda małżeńska, jako przyczyna sprawcza małżeństwa, znajduje się w centrum istoty konwalidacji. Albowiem jeśli jej nie było, możemy zastosować jedynie kanony dotyczące konwalidacji zwykłej, natomiast jeśli zgoda była i nie została odwołana przez żadną ze stron, możemy stosować drugą formę konwalidacji, a mianowicie sanatio in radice, oczywiście przy zachowaniu stosownych warunków (Dacanáy 2000, 252).

Poddając analizie obydwie formy konwalidacji, należy zauważyć, iż w wypadku konwalidacji zwykłej wymaga się ponowienia zgody małżeńskiej, przynajmniej przez stronę świadomą przeszkody (kan. 1133 § 1 Codex Iuris Canonici '1917, kan. $1156 \S 1$ KPK, kan. 843 § 1 Kodeksu Kanonów Kościołów Wschodnich). Natomiast uzdrowienie w zawiązku jest konwalidacją bez ponawiania zgody, dokonaną przez kompetentną władzę (kan. 1138-1140 CIC ’1917, kan. 1161

${ }^{4}$ „Zgoda małżeńska jest aktem prawnym, który z natury swojej nie ulega stopniowaniu i jest niepodzielny: albo jest i wówczas jest wystarczający, albo go nie ma, i wówczas w ogóle go brak".

${ }^{5}$ „W rzeczywistości wole wewnętrzne i pakt małżeński są dwiema fazami tego samego procesu wytworzenia przyczyny sprawczej małżeństwa. [...] kiedy dzięki dostrzegalnemu znakowi małżeństwa, dwoistość woli materializuje się w jedyny pakt, który jest manifestowany przez strony i rozpoznawalny przez Kościół, wówczas proces wytworzenia skutecznej przyczyny jest doskonały, a pakt małżeński, czyli - zgodnie z kan. 1057 - zgoda wyrażona zgodnie z prawem między osobami prawnie do tego zdolnymi, jest przyczyną węzła małżeńskiego".

${ }^{6}$ „The Code specifies two kinds of validations and determines their essential elements: simple validation and retroactive validation (sanatio in radice). Simple validation is the process by which an invalidly contracted marriage is rendered valid by the renewal or the giving of consent of at least one party for various hypotheses as contemplated by cc. 1156-1160. This does not effect canonical effects to the past. On the other hand, sanatio in radice is the validation of a marriage in which there is no renewal of consent and by means of which canonical effects are retroacted into the past by fiction of law. From these descriptions, there are real differences between these two mechanisms". 
$\S 1 \mathrm{KPK}$, kan. $848 \S 1 \mathrm{KKKW})$. Jest to podstawowa różnica między dwiema formami konwalidacji. A zatem w uzdrowieniu w zawiązku do konwalidacji małżeństwa dochodzi na podstawie pierwotnej, istniejącej już zgody małżeńskiej. Dlatego prawo kanoniczne na oznaczenie tego specyficznego sposobu uważnienia aktu prawnego używa trafnie i celowo wyrażenia sanatio a nie validatio lub convalidatio. Instytucja ta oznacza bowiem uzdrowienie lub uzupełnienie pewnych braków w czymś, co samo w sobie już istnieje w sposób wystarczający i pełny. Nie jest to stwarzanie z niczego całkiem nowej rzeczy, lecz jest to tylko samo uzdrowienie z niemocy prawnej tego, co już istnieje w płaszczyźnie naturalnej, czyli in obiectiva rerum natura (Rybczyk 1958, 17). Konwalidacja zwykła charakteryzuje się wyrażeniem zupełnie nowej zgody małżeńskiej, występującej jako zupełnie odrębny akt woli (Le Tourneau 1988, 111) ${ }^{7}$. Dochodzi więc do sytuacji, w której mamy do czynienia ze stanem, w którym po usunięciu przeszkody albo uzyskaniu od niej dyspensy, nupturienci są de facto zobowiązani do powtórnego wyrażenia zgody małżeńskiej, aby mogło się ukonstytuować małżeństwo. Podobna sytuacja ma miejsce, gdy idzie o brak zdolności konsensualnej czy też o wady oświadczenia woli choćby jednego z nupturientów. Zgoda małżeńska, jeśli nie jest obciążana żadnym brakiem lub defektem, staje się zupełnie inną zgodą na małżeństwo. W ten sposób osoby kontrahentów stają się osobami zdolnymi do zawarcia małżeństwa. A zatem ponowienie zgody nie może stać się potwierdzeniem poprzedniego, nieważnie danego zezwolenia na małżeństwo, lecz musi być - jak zauważa F. Bączkowicz - nowym aktem woli, różnym od poprzedniego, a wyrażonym po uświadomieniu sobie nieważności małżeństwa i usunięciu istniejących przeszkód (Bączkowicz 1933, 179). Co więcej, zgodnie z kan. 1156 $\S 2$ KPK ponowienie zgody jest wymagane przez prawo kościelne do ważności uważnienia, chociażby na początku obydwie strony wyraziły zgodę i potem jej nie odwołały (kan. 1133 § 2 CIC '1917, kan. $843 \S 2$ KKKW). Ten przepis znajduje swoje źródło w kan. 1057 § 1 KPK, według którego zgoda małżeńska nie może być uzupełniona żadną ludzką władzą. Podobnie sytuacja wygląda w przypadku nieważności małżeństwa na skutek braku formy - zgodnie z kan. 1160 KPK dokonanie konwalidacji małżeństwa musi nastąpić przez ponowne zawarcie małżeństwa w przepisanej formie, która oczywiście wymaga złożenia oświadczenia woli, a więc wyrażenia zgody małżeńskiej przez te osoby. W przypadku zastosowania sanatio in radice na skutek braku formy kanonicznej, mamy możliwość zaobserwowania interesującej sytuacji. Jak zauważa O. Robleda, pominięcie formy kanonicznej nie kreuje węzła małżeńskiego (Robleda 1964, 138). Mamy zatem do czynienia z konsensem wprawdzie skutecznym naturalnie, ale niewystarczającym do uzyskania skuteczności prawnej w kanonicznym porządku prawnym. Mowa jest zatem o matrimonium inexistens, a nie małżeństwie nieważnym. $\mathrm{Z}$ racji na

${ }^{7}$ "Ce renouvellment est requis pour la validité de la convalidation; il constitue un nouvel acte de volonté pour ce mariage connu comme étant nul depuis son commencement". 
samą zgodę małżeńską i spełnienie warunków normy kan. 124 § 1 KPK istnieje jednak możliwość, po udzieleniu dyspensy przez kompetentną władzę, na sanowanie takiego małżeństwa. Należy powtórzyć raz jeszcze, że idzie tu o konsens naturalnie wystarczający, lecz jurydycznie nieskuteczny (Dzierżon 2001, 29).

Warto zauważyć, iż przy zwykłej konwalidacji współpraca stron jest czynnikiem zasadniczym, bez którego konwalidacja nie może dojść do skutku. Ta właśnie współpraca wyraża się poprzez ponowne wyrażenie zgody małżeńskiej (Cappello 1923,888$)^{8}$. W przypadku uzdrowienia w zawiązku mamy zaś do czynienia z dopełnieniem przez kompetentną władzę warunków koniecznych do ważności małżeństwa, przy jednoczesnej zachowanej zgodzie zawierających małżeństwo. Co ważne, taka zgoda może być udzielona bez wiedzy jednej lub obydwu stron. Prawodawca stawia jednak jeden warunek, którym jest istnienie poważnej przyczyny. Jak zauważa W. Góralski, może nią być np. znajomość przyczyny nieważności małżeństwa tylko przez jedną stronę, wraz z obawą, że ujawnienie jej współkontrahentowi będzie dlań stanowić poważne zło. Inną przesłanką może być nieważność małżeństwa, która wyniknęła z braku formy spowodowanej nieuwagą duchownego w sytuacji, kiedy groziłoby mu zniesławienie lub nawet zgorszenie stron zaistniałą sytuacją (Góralski 2011,367).

\section{SKUTKI KONWALIDACJI MALŻEŃSTWA}

Konwalidacja małżeństwa wywołuje określone skutki. Jako akt prawny pociąga za sobą skutki w sferze prawnej. Oczywiście podstawowy, a zarazem odnoszący się zarówno do konwalidacji zwykłej, jak i sanatio in radice jest ten, że obydwa te sposoby zmierzają do uznania małżeństwa za ważne na forum kanonicznym. Uzupełnione zostają wymogi formalne do tego, aby akt prawny zawarcia małżeństwa nie zawierał już żadnej przesłanki czyniącej go nieważnym. Jednak w zależności od tego, z jaką formą konwalidacji mamy do czynienia, można mówić o różnych terminach wywierania skutków prawnych.

Przy zwykłej konwalidacji, jak to już zostało powiedziane, powstaje związek małżeński na podstawie aktualnie wyrażonej zgody małżeńskiej. Prawodawca w kan. 1159 § 1 KPK stanowi, że małżeństwo nieważne z powodu braku zgody zostaje uważnione z chwilą wyrażenia zgody przez stronę, która jej nie wyraziła, jeśli trwa zgoda wyrażona przez drugą stronę. Zatem konwalidacja zwykła wywołuje skutki od momentu wyrażenia zgody. Nie jest to oczywiście ponowienie zgody wcześniejszej, albowiem żadna ludzka władza nie jest w stanie tej zgody zastąpić czy też ją uzupełnić. Ponowienie zgody małżeńskiej ma być nowym aktem woli kontrahentów (Góralski 2006, 353). Stąd też wyrażenie convalidatio,

${ }^{8}$, ,Nam convalidatio simplex id efficit per novum consensum, etiam in casu quo consesnus naturaliter validus iam datus fuerit et adhuc perseveret, et ideo per cooperationem coniugum". 
odnoszące się do konwalidacji zwykłej, jest tu całkiem na miejscu, gdyż oznacza powstanie czegoś nowego bez odnoszenia się do przeszłości (Rybczyk 1958, 20). Jeśli jednak małżeństwo było zawarte w dobrej wierze przynajmniej przez jedną stronę, należy stwierdzić, iż przysługują mu przywileje właściwe dla małżeństwa domniemanego.

Uzdrowienie w zawiązku zgodnie z kan. $1161 \S 2$ KPK następuje od chwili udzielenia łaski, a cofnięcie skutków odnosi się do momentu zawarcia małżeństwa, chyba że co innego wyraźnie zastrzeżono. Mamy zatem do czynienia z instytucją retroakcji. Retroakcja oparta jest na fikcji prawnej, o której decyduje pozytywna wola prawodawcy. Retroakcja dotyczy oczywiście skutków prawnych, a nie samego sanatio in radice. Jak zauważa W. Góralski, pozytywna wola prawodawcy pełni rolę czynnika konstruktywnego, który powołuje do życia skutki prawne o mocy retroaktywnej, a sama fikcja prawna, a także retroakcja, są tylko środkami prawnymi, inaczej elementami pomocniczymi, dzięki którym prawodawca osiąga zamierzony cel (Góralski 1986, 351). Uzdrowienie w zawiązku obejmuje zatem swoimi skutkami nie tylko czas przyszły, lecz także i czas przeszły, gdyż sięga do samego początku zawierania małżeństwa. Natomiast zwykła konwalidacja dotyczy tylko czasu przyszłego (Rybczyk 1958, 266).

Podstawowym skutkiem prawnym płynącym z ważnego małżeństwa jest powstanie wieczystego i wyłącznego węzła małżeńskiego pomiędzy małżonkami (kan. 1134 KPK). Natomiast skutkiem nadprzyrodzonym jest sakrament. Małżeństwo konwalidowane cieszy się już zatem pełnią skutków jurydycznych. Należy w tym miejscu zaznaczyć, iż wypośrodkowując między wewnętrzną wolą i wymogami pewności prawnej, kan. 124 § 2 KPK domniemywa ważność aktu prawnego „właściwie dokonanego w jego elementach zewnętrznych”. Jest to domniemanie zwykłe, dotyczące ważności aktu, a nie jego istnienia (Sobański 2003, 204).

Pewne różnice dostrzegamy również w kwestii legitymacji potomstwa. Gdy idzie o konwalidację nadzwyczajną, to potomstwo z takiego małżeństwa uważane jest za takie, jak gdyby pochodziło od samego początku z małżeństwa ważnie zawartego. Związane to jest z samą naturą sanatio in radice, uwidocznioną od samego początku tejże instytucji (Rybczyk 1958, 62-80). Nadto w kanonistyce legitymacja wynikająca z uzdrowienia w zawiązku nazywana jest często legitimatio plenissima. Warto jednak zauważyć, że są kanoniści - jak np. F. Bersini - którzy twierdzą, iż przy tej konwalidacji uzyskuje się nie tyle legalizację potomstwa, ile ich prawe pochodzenie (Bersini 1983, 170). Inna sytuacja ma miejsce przy zwykłej konwalidacji. Tutaj należy zastosować normę kan. 1139 KPK. A zatem legitymacja potomstwa następuje $\mathrm{w}$ drodze późniejszego zawarcia małżeństwa przez rodziców dziecka albo poprzez reskrypt Stolicy Apostolskiej. W kolejnym kanonie prawodawca stwierdza, iż co do skutków kanonicznych dzieci, które uzyskały prawność pochodzenia, są zrównane we wszystkim z dziećmi prawego pochodzenia, chyba że prawo wyraźnie co innego zastrzega. 


\section{PODSUMOWANIE}

Po przeanalizowaniu problematyki konwalidacji małżeństwa kanonicznego warto podkreślić nieścisłości terminologiczne odnoszące się do pojęcia konwalidacji. Przede wszystkim tłumaczenie na język polski nie oddaje w pełni znaczenia pojęciowego terminu „konwalidacja”. Słowo „uważnienie” często używane jest zarówno w odniesieniu do sytuacji zwyczajnej, jak i nadzwyczajnej, pomimo że istnieje generalna różnica między nimi. Zdaję sobie sprawę z tego, iż nazwa „uważnienie” funkcjonuje w polskiej terminologii kanonistycznej, jednak byłoby wskazane posługiwanie się określeniem „konwalidacja”. Konwalidacja małżeństwa jest bardzo znaczącą instytucją kanonicznego prawa małżeńskiego, wywołującą daleko idące skutki. Polega na uzyskaniu skuteczności prawnej czynności, jaką jest zawarcie małżeństwa w systemie prawa kanonicznego. Dodajmy - małżeństwa, które przecież funkcjonuje już w obrębie społeczności, jest postrzegane jako takie i, co więcej, ma zamiar trwać w przyszłości.

\section{BIBLIOGRAFIA}

\section{Źródla}

Codex Iuris Canonici Pii X Pontificis Maximi iussu digestus Benedicti Papae XV auctoritatae promulgatus, Romae 1927.

Codex Iuris Canonici auctoritate Ioannis Pauli PP. II promulgatus. 1984. Przekł. polski zatwierdzony przez Konferencję Episkopatu. Poznań: Pallottinum.

Encyklopedia popularna PWN. 1982. Warszawa: PWN.

Jougan, Alojzy. 2013. Stownik kościelny łacińsko-polski. Sandomierz: Wydawnictwo Diecezjalne i Drukarnia w Sandomierzu.

Katechizm Kościoła Katolickiego (KKK). 2002. Poznań: Pallottinum.

Kodeks Kanonów Kościołów Wschodnich promulgowany przez Jana Pawła II, Wydawnictwo Archidiecezji Lubeslskiej „Gaudium” 2002.

Kopaliński, Władysław. 1989. Słownik wyrazów obcych i zwrotów obcojęzycznych. Warszawa: Wiedza Powszechna.

Korpanty, Józef (red.). 2003. Stownik łacińsko-polski. T. 2. Warszawa: Wydawnictwo Szkolne PWN.

Sobór Watykański II. 2002. „Konstytucja duszpasterska o Kościele w świecie współczesnym Gaudium et spes". W Sobór Watykański II. Konstytucje, dekrety, deklaracje. 526-606. Poznań: Pallottinum.

Szkiłądź, Hipolit (red.). 1980. Słownik wyrazów obcych. Warszawa: PWN.

\section{Literatura}

Bączkowicz, Franciszek. 1933. Prawo kanoniczne. Podręcznik dla duchowieństwa. T. 2. Kraków: Drukarnia Polska Franciszka Zemanka.

Bersini, Francesco. 1983. Il nuovo diritto canonico matrimoniale. Torino: Elledici.

Biskupski, Stefan. 1956. Prawo matżeńskie Kościoła rzymskokatolickiego. T. 1. Warszawa: Instytut Wydawniczy „Pax”.

Brennan, James. 1937. The simple convalidation of marriage. Washington: The Catholic University of America Press. 
Cappello, Felice M. 1923. Tractatus canonico-moralis de sacramentis iuxta Codicem Iuris Canonici. Vol. 3. Torino: Marietti.

Chelodi, Ioanne. 1921. Ius matrimoniale iuxta Codicem Iuris Canonici. Trento: Tridentum.

Dacanáy, Adolfo N. 2000. Canon Law on Marriage. Manila: Ateneo de Manila University Press.

Dzierżon, Ginter. 2000. „Aplikacja kategorii aktu prawnego w kanonicznym prawie małżeńskim”. Ius Matrimoniale 5 (11): 9-21.

Dzierżon, Ginter. 2001. „Nieważność małżeństwa oraz niezaistnienie małżeństwa w kanonicznym porządku prawnym”. Ius Matrimoniale 6 (12): 7-31.

Dzierżon, Ginter. 2002. Niezdolność do zawarcia matżeństwa jako kategoria kanoniczna. Warszawa: Wydawnictwo Uniwersytetu Kardynała Stefana Wyszyńskiego.

Gajda, Piotr M. 2002. Prawo matżeńskie Kościoła katolickiego. Tarnów: Wydawnictwo Diecezji Tarnowskiej Biblos.

Gerosa, Libero. 2002. Canon Law. Berlin-Hamburg-Münster: Bloomsbury Academic.

Góralski, Wojciech. 1986. „Małżeństwo”. W Komentarz do Kodeksu Prawa Kanonicznego. T. 3. Red. Piotr Hemperek, Wojciech Góralski, Franciszek Przytula, Józef Bakalarz. 213-357. Lublin: Redakcja Wydawnictw Katolickiego Uniwersytetu Lubelskiego.

Góralski, Wojciech. 2006. Kościelne prawo matżeńskie. Warszawa: Wydawnictwo Uniwersytetu Kardynała Stefana Wyszyńskiego.

Góralski, Wojciech. 2007. „Miejsce zgody małżeńskiej w strukturze prawnej małżeństwa kanonicznego". W Studia nad matzeństwem i rodzina. 305-318. Warszawa: Wydawnictwo Uniwersytetu Kardynała Stefana Wyszyńskiego.

Góralski, Wojciech. 2011. „Uważnienie małżeństwa”. W Komentarz do Kodeksu Prawa Kanonicznego. T. 3.2. Red. Józef Krukowski. 359-368. Poznań: Pallottinum.

Góralski, Wojciech, Ginter Dzierżon. 2001. Niezdolność konsensualna do zawarcia matzeństwa kanonicznego. Warszawa: Wydawnictwo Uniwersytetu Kardynała Stefana Wyszyńskiego.

Hervada, Javier. 1987. „La convalidazione del matrimonio”. W Codice in Diritto canonico. Navarra-Roma: Logos.

Ignatowicz, Jerzy. 2002. Prawo rodzinne. Warszawa: Wydawnictwo Prawnicze LexisNexis.

Janczewski, Zbigniew. 2008. „Konwalidacja zwykła małżeństwa”. W Leksykon obywatela. Red. Sławomir Serafin, Bogumił Szmulik. Warszawa: C.H. Beck.

Kasprzak, Sylwester. 2000. Wybrane zagadnienia z prawa kościelnego. Lublin: Wydawnictwo Diecezjalne w Sandomierzu.

Le Tourneau, Dominique. 1988. Le droit canonique. Paris: Presses Universitaires de France.

Leszczyński, Grzegorz. 2004. Osoba ochrzczona niewierzaca a sakrament matżeństwa. Łódź: Archidiecezjalne Wydawnictwo Łódzkie.

Pawluk, Tadeusz. 1984. Prawo kanoniczne wedtug kodeksu Jana Pawła II. T. 3. Olsztyn: Warmińskie Wydawnictwo Diecezjalne.

Rava, Alfredo. 2001. Il requisito della rinnovazione del consenso nella convalidazione semplice del matrimonio (can. 1157 \& 2). Roma: Gregorian Biblical BookShop.

Robleda, Olis. 1964. La nulidad del acto juridico. Roma: Gregorian Biblical BookShop.

Rybczyk, Jerzy. 1958. Uzdrowienie matżeństwa w zawiązku (Sanatio in radice - c. 1138-1141). Lublin: Towarzystwo Naukowe Katolickiego Uniwersytetu Lubelskiego.

Sobański, Remigiusz. 2003. „Czynności prawne”. W Komentarz do Kodeksu Prawa Kanonicznego. T. 1. Red. Józef Krukowski. 201-212. Poznań: Pallottinum.

Szafrański, Władysław. 1971. Rzymskokatolickie prawo małzeńskie po drugim Soborze Watykańskim. Poznań-Warszawa-Lublin: Wydawnictwo Świętego Wojciecha.

Sztafrowski, Edward. 1979. Prawo kanoniczne w okresie odnowy soborowej. T. 2. Warszawa: Akademia Teologii Katolickiej. 
Sztafrowski, Edward. 1986. Podręcznik prawa kanonicznego. T. 4. Warszawa: Akademia Teologii Katolickiej.

Tallarico, Carolus J. 1938. De matrimonii convalidatione. Roma: Athenaeum Antonianum.

Viladrich, Pedro Juan. 2002. Konsens matżeński. Sposoby prawnej oceny i interpretacji w kanonicznych procesach o stwierdzenie nieważności matzeństwa. Tł. Seweryn Świaczny. Warszawa: Wydawnictwo Uniwersytetu Kardynała Stefana Wyszyńskiego.

Wernz, Franciscus, Petrus Vidal. 1925. Ius canonicum. T. 5. Roma: Pontificia Universitas Gregoriana.

Żurowski, Marian. 1976. Kanoniczne prawo matżeńskie okresu posoborowego. Katowice: Księgarnia Świętego Jacka.

\title{
Adam Bartczak
}

\section{THE CONVALIDATION OF MARRIAGE IN CANON LAW}

\begin{abstract}
The convalidation of marriage in canon law is a process where the invalidly contracted marriage becomes validly contracted in the light of law. The author of this article analyses the notion of the convalidation of the marriage, basing on Polish canon law literature and on opinions of different authors. In canon law there are considerable differences between two kinds of the convalidation: convalidatio simplex and sanatio in radice. In Polish literature there exists only one word denoting these two kinds. This institution is of vital importance in canon law, as it has a legal effect on the marriage, which de facto exists in reality.
\end{abstract}

Keywords: matrimonial, effectiveness, convalidation, the consent of the parties, defect. 